\title{
The Battle of the Skamander ${ }^{1}$
}

"In the 'Picador' period and later in the Skamander period, we were terrible. Young, witty, cruel, and, to make things worse, with money. Simply disgusting", as Antoni Słonimski reminisced on his youth ${ }^{2}$. Sometimes, their wittiness - and certainly their cruelty - was equalled by that of Adolf Nowaczyński. Therefore, in this respect, though not only it, there must have been some rivalry between them.

The relationships between Skamandrites and the leading commentators of the nationalist camp were not easy. As Jan Lechon indicated in Dziennik, Nowaczyński fascinated Mieczysław Grydzewski³. This was why until the end of the interwar period - despite some prior disputes, which I shall discuss later on - there was a space reserved for him in the Wiadomości Literackie, though Grydzewski printed only his historical texts. It was Kazimierz Wierzyński who was on a first-name basis with Nowaczyński (and he published the latter one's texts in his Poznań-based Kultura). As for Słonimski, the situation was more complicated, which led to a duel of a kind that is worthy of a story.

The satirist and dramatist, one of the greatest writers of the second period of the Young Poland, met the nearly twenty years younger sketch artist (and secretly a poet) in Warsaw occupied by Kaiser's forces, in the editorial

1 The title was proposed in Kronika Tygodniowa in the "Wiadomości Literackie" journal, 1927, issue 25 of 19 June. It was Antoni Słonimski's second ever "Chronicle".

2 A. Słonimski, Załatwione odmownie. Seria druga, Warsaw 1964, p. 91. [Unless indicated otherwise, quotations in English were translated from Polish]

3 In March 1921, Lechoń - still ill after an attempted suicide - was so focused on the visit of Nowaczyński and Helena Sulima, his sister-in-law, that he ignored a visit by Jarosław Iwaszkiewicz, which humiliated the latter greatly: "I have never and nowhere been welcomed worse”. Cf. J. Iwaszkiewicz, Książka moich wspomnień, Kraków 1983, p. 373. 
office of the satirist Sowizdrzat weekly. "At that time, I ate at the Dakowski pastry shop in Napoleon Square. The pastry cook enabled us to eat for free once a week in return for publishing his announcement in the Sowizdrzat. He had the right to hold our editorial meetings there enjoying free yeast cakes and excellent coffee with cream", as Słonimski reminisced. "Even Winawer, Nowaczyński, Rzymowski, and Lechon, as well as the painters Romanowicz and Grabowski came in ${ }^{\prime \prime 4}$. The description of the rest of the week of the brotherhood was depicted by Nowaczyński himself, who, actually, at that time was someone like a deserter: "Terrible poverty and misery: rubber collars (literally), nettle coats (literally); the better clothes already sold. Eating: groats, flour, saccharin, dry vegetables, black bread from the noble Zyglarski in Bracka St., who supported the writer and journalist community and who was patient as Job. Black coffee made from peas or beans, pipe cigars made of oak leaves, methyl vodka, gooseberry wine ${ }^{\prime \prime 5}$. This brought them close.

When establishing the Skamander poetic monthly in the late 19196, Mieczysław Grydzewski came up with a cunning idea to coax from a few writers of the older generation something akin to intellectual promissory notes, payable in the undefined future. Therefore, the talent of Skamandrites was vouched for to readers by Juliusz Kaden-Bandrowski, Wincenty Rzymowski, Adolf Nowaczyński, and Karol Irzykowski. The last one protested already after the first issue; he distanced himself from the young writers in his article Programofobia ${ }^{7}$ and viciously summarised their tactics in the polemic titled Po gościnie u 'Skamandra'8. Similar emotions must have pestered Nowaczyński, who paid for that visit with a somewhat heroic yet momentary damming of his anti-Semitism: "If independent Poland currently has 13\% Hebrews, then Skamander's galleon has no more than 3\%. (...) In Skamander's poetic arboretum, there freely grow all the flowers of sin and virtue, rapture and exaltation, and despite intensive sense of smell for that end, I could not pick up the scent of neither garlic or onion"9. Such an argumentation irritated Irzykowski and both "older gentlemen" had a serious falling out:

His polemic with Mr Pieńkowski regarding whether the Skamander group is Jewish or not is incomprehensible for those who are not familiar with the behind-the-scenes events of the Rzeczpospolita and the Gazeta Warsz. camps. In fact, Nowaczyński himself in his "Liberum Veto" saw Jews everywhere tracking them like some trained hound ${ }^{10}(. .$.$) Instead$

${ }^{4}$ A. Słonimski, Władysław Nawrocki, [in:] Alfabet wspomnień, Warsaw 1989, p. 162.

5 A. Nowaczyński, W pierwszym pułku Pierwszej Brygady, [in:] Stowa, słowa, słowa..., Warsaw 1938, p. 326.

${ }^{6}$ The "Skamander" journal was presented for the first time during the evening meeting on 6 December, 1919, in the Hygienic Association at 31 Karowa Street.

7 K. Irzykowski, Programofobia, "Skamander" 1920, issue 2.

${ }^{8}$ K. Irzykowski, Po gościnie u 'Skamandra', "Skamander" 1921, issue 4.

9 A. Nowaczyński, Skamander połyska, wiślana świetlący się fala, [in:] Góry z piasku. Szkice, Warsaw 1922, pp. 158-159. Originally printed in: "Skamander" 1921, issue 7/9.

${ }^{10}$ It applied to the second, Warsaw-based and 'nationalist' "Liberum Veto", which Nowaczyński circulated illegally in 1918-1919. 
of completely mocking such an approach, that is for one's race or faith to decide about one's entitlement to literary citizenship, the impish Mr Nowaczyński noted in the case of Tuwim and Słonimski that... "they do not smell of garlic or onion," which he, Nowaczyński, the recognised specialist in scents, warranted. So Nowaczyński agreed with Pieńkowski completely about the onion criterion of poetry, and the entire war between the two augurs of anti-Semitism consisted only of one of them noticing onion in the poems, while other did not! That is one peculiar way of discussing and evaluating literature! ${ }^{11}$

This aspect of the issue was approached with surprising tolerance by Skamandrites. One can only infer that they considered the aggressive anti-Semitism as a kind of guise of the commentator. Today, however, it is difficult not to feel the chills when reading the massacre visions in Nowaczyński's accounts from the broken off evening by Tuwim and Słonimski in Drohobych: "Oh, you frogs chortling in the swamps of the Jewish Ghetto! You will finally have your grand Drohobych! You will get it!"12 Despite this, in unofficial relations they also turned a blind eye to the opinions by Kornel Makuszyński as well as subsequent practices of Kazimierz Grus and Jerzy Zaruba, the collaborators of Wiadomości Literackie, who posted rude anti-Semitic caricatures through other media.

However, in the first weeks of 1923, there also occurred a breaking off of their relations. The reason for that was not the poetry of Skamandrites but Nowa Szopka Pikadora [A New Play by Pikador], the second in turn (earlier premièring on 8 February), the text of which has sadly been almost entirely lost $^{13}$. This was the play which Zaruba discussed:

I remember when one year a popular play by the Cyrulik was supposed to be staged in Belweder. That was organised by Wieniawa, a friend of the authors of the play. An army truck took the disassembled building, two baskets of dolls, myself, Leonhard, and the machine operator. When the play building was erected and the curtains were hung, we started refreshing some of the already somewhat tattered dolls. Leonhard was an excellent puppeteer and he enjoyed playing with them like a child.

When Witold was making corrections to the puppet of the marshal, suddenly the curtain moved and Piłsudski himself stepped in. Leonhard hid the puppet behind his back and said to Piłsudski:

"I am sorry. You can't look now - this won't seem funny."

Piłsudski moved his moustache and left. That was probably the only instance when someone dared to say to Piłsudski: "you mustn't."14

${ }^{11}$ K. Irzykowski, Kalamburda warszawski, [in:] Pisma rozproszone, vol. 1, 1897-1922, Kraków 1998, p. 556. Originally printed in: “Trybuna” 1921, issue 27.

12 A. Nowaczyński, Na występach w Drohobyczu..., "Myśl Narodowa” 1923, issue 49, p. 15.

${ }^{13}$ Surviving snippets in: M. Hemar, J. Lechon, A. Słonimski, J. Tuwim, Szopki 1922-1931 Pikadora i Cyrulika Warszawskiego, ed. T. Januszewski, Warsaw 2013, pp. 77-80.

14 J. Zaruba, Z pamiętników bywalca, Warsaw 1968, p. 116. 
The thing is that, according to the surviving list of characters, the Piłsudski puppet was the one which was not used in the play ${ }^{15}$. Quoting from Słonimski's recollections:

...to our sadness we learnt from the afternoon press that Marshal summoned for the same time a Council of Ministers at Belweder. We were sorry because we had been delighted about the visit with the play for several days now $^{16}$. But before four, Wieniawa appeared at Astoria and took us because it turned out that the play was actually going to happen. Piłsudski did summon a Council of Ministers, and when the ministers arrived, he said: "Gentlemen, accompany me to a play."17

When driving in Piłsudski's black Packard (according to other sources, it was - which was actually true - a Cadillac), Tuwim supposedly called ecstatically: "Damn! What fun it would be to now run some acquaintance over!"

The events could be somewhat explained by the historical context. On 16 December of the previous year, Gabriel Narutowicz, the first president of the Second Polish Republic, was assassinated. Both poets, and both being the authors of shocking poems condemning the event, immediately afterwards took to writing a light-hearted play. Not just that. On 30 December, the trial of Eligiusz Niewiadomski, the assassin, began; on 10 January, the sentence was announced; and on 31 January, he was executed. It would seem that the authorities should have been deeply solemn or even in mourning. Yet, Władysław Sikorski's cabinet and the former Chief of State were enjoying themselves at a play.

With his typical logic, Nowaczyński considered the crime of the fanatic nationalist as a sign of the coming Jewish terror:

If we recall now with a clear mind the percentage of Jews living among us and if we realise the imperative tone with which they write today, after the assassination by the madman so fortunate for them, it becomes clear for us the whole terrible void which opened in front of us. (...) no longer centrists, or Esers, or NPs, or Mensheviks, or PPSers take to rule, but the cruel vindictive eastern Jews (!), plunging their hands in the warm Polish blood. ${ }^{18}$

Two weeks after the assassination, he expanded on his thought: "It is all about that one minority, that human demon, that Antichristic single minority, i.e. the Jewish plague, with the demonic powers of which Europe

${ }^{15}$ M. Hemar, J. Lechon, A. Słonimski, J. Tuwim, Szopki 1922-1931 Pikadora i Cyrulika Warszawskiego...

${ }^{16}$ On Sunday 18 February, Tuwim notified his wife: "Piłsudski invited us on Thursday to the staff (with the play)." It was staged on 22 February, two weeks after the première. As in: M. Hemar, J. Lechoń, A. Słonimski, J. Tuwim, Szopki 1922-1931 Pikadora i Cyrulika Warszawskiego..., p. 329.

17 A. Słonimski, Belweder, [in:] Alfabet wspomnień, p. 17. Contrary to the recollections, Piłsudski, only the chief of the General Staff, did not have the right to summon government meetings.

18 A. Nowaczyński, Po zamachu, "Myśl Narodowa”, 1922, issue 51, pp. 2-6. 
and the whole world is fighting to the death. (...) Poland is the hatchery of Semi microbes spreading through the world (...) That vampire sucks at our throat"19. The Testament exposed him to a short-term trial under the accusation of "glaring solidarity with the crime". He was, however, acquitted.

Nowaczyński's recent fear of his imagined revenge of "global Jewishness" was condensed in Szopka. "After the première, he came backstage and praised that «wonderful», that «ingenious», that «Zielony Balonik [the Green Balloon comedy group] popped»", as Słonimski reported. "He kissed us yet from Myśl Narodowa we learnt the following morning that «donkey hooves» and «stinks of onion». I met him afterwards and asked: «What did you write there?» «Where?» he responded. «In Myśl Narodowa». «It wasn't me», he said. «What do you mean? It was signed A. N. and you say it wasn't you?» «I can't remember». «So neither can I», I ended the conversation" ${ }^{20}$. As I have already mentioned, the play with Szopka could have raised some moral reservations. However, it was not those that drew the attention of the pamphleteer. There was no way he would step outside his regular themes:

In the grand Jewish Aquarium, in "Żemjanska Kawiarnia" run by the oberspiv Albrecht, there are held new stagings of this year's Szopka, ganz kosher this time, written exclusively by ritually circumcised three. Since Lechon is sick and other poets yield to the Jewish invasion and withdraw from literature (...) one can imagine the tendency of such a majufes (...) p-I-C-A-dors' Szopka was written not in the jargon but in Polish so also those Polish scum who find themselves in that mikveh of kosher humour could understand how the capital of Poland is ridiculed by those last Mohicans still fighting against the complete Jewishing of Kikesaw and Poland. ${ }^{21}$

Yet the true sensation broke after the performance of Szopka at Belweder. The pamphlet, signed this time, covered a six-column editorial in Myśl Narodowa. While holding the Szopka authors in contempt, Nowaczyński had a goal to exact the most severe of mockery of the Marshal's "intellectual level, taste, fancy, and disposition":

Mr Piłsudski offered a fresh proof of his somewhat Russian world view and indicated how the ugly vengefulness and shallow meanness have grown in the soul of the eliminated too late Imposter. Two talented yet wildly overrated kike comedians, conjurers and epigones of Russian realms of Mayakovskism, Burliukism ${ }^{22}$, and Yeseninism wrote a new Szopka, a "Neues Kukiełkes", in which taking revenge for knocking off that regent (who let half a million Russian Jews into Poland and led the country to ruin), with particular fury pounced at the periodical and the pens which

19 Idem., Testament, “Myśl Narodowa” 1923, issue 1, pp. 4-5.

20 A. Słonimski, Nowaczyński Adolf, [in:] Alfabet wspomnien, p. 171. Truth be told, the note to which I am referring is not signed.

${ }^{21}$ Nowa szopka Pikusiów, "Myśl Narodowa" 1923, issue 7. The title alluded to Józef Urstein 'Pikuś, the actor of Qui Pro Quo (1884-1923). On 7 October of that year, this pioneer of szmonces died a humourist death to a heart attack during the intermission of the Będzie lepiej play.

${ }^{22}$ Surely a reference to futurist artists David and Nikolai Burliuk. 
largely caused the toppling of the Marshal of marsheliks, i.e. on Professor Stroński and on Ms. Pannenkowa from the Rzeczpospolita. (...) For example, (...) the raging vippers of the Ghetto dared on billboards in Warsaw! in Poland's capital! to call Reymont "pissage polonaise"! (!)

It is those "Neues Kukiełkes" from the Ziemiańska café that Pericles Piłsudski considered worthy of receiving at the General Staff where "the elite of the army gathered with no omission together with their families." The comedian sat in the middle on a stool leaning on a huge sword, while young Jankiels started playing on cimbalons their concert of concerts. (...)

And the "man of the East", or that one from the Kremlin, or this one from the Saski Square from all the Arts only recognises and has a taste for comedy... for Szopkas... for maybe even skilled yet impudent Jewish clowns smelling and pissing on the opposition's wall.

Bonaparte had at least Talma, this Malparte has... Słowim... from Mayakowskism... ${ }^{23}$

This particular publication, in which - according to its author's intentions - the army quasi-genius and the dissolute quasi-artists disgraced each other, while both sides were supposed to be humiliated by the (not quoted here) erudite parallel to Napoleon's biography, proved the pit of offence for Skamandrites. That which they endured when it was directed at them, they could not stand when it was directed at Marshal Piłsudski. Not only did someone spoil their holiday, but they also struck at that which was sacred. The shock they experienced, or which Słonimski experienced, for whom Piłsudski was the crowning of his family legend ${ }^{24}$, triggered the most vicious pamphlets in the history of Polish literature. It raised doubts even among the author's friends. Lechon thus wrote to Grydzewski: “The ghastly Tolek! Painfully unjust, despicably libellous, foul and shameless, yet wildly and savagely comical". Anna Iwaszkiewicz, Słonimski's confidant, noted in Dzienniki: "It is, in its kind, a good pamphlet, (...) yet such a thing should have ever been published in Skamander" 25 .

Since the Rudy do budy! pamphlet, historians have traced the common opinion of Słonimski as a hellishly formidable pamphleteer, which he maintained for nearly fifty years, i.e. till the end of his life. A close inspection of the text, which - apart from a few sentences - actually constituted its victim's curriculum vitae, would indicate the richness of the rhethorical devices applied in it; particularly those ironically recommended in the well-known treatise by Arthur Schopenhauer. Of course, Grydzewski was mistaken in stating that "the humour of that parody also consisted of the fact it included

23 A. Nowaczyński, L'ex-roi s'amuse, czyli 'Neues Kukiełkes', “Myśl Narodowa” 1923, issue 9, pp. 1-6.

${ }_{24}$ As Słonimski described it, during a post-show evening meal the Marshal honoured him with a conversation. "«Be you the doctor's son?» «Yes, sir», I responded. «I remember. Under six». «No, Marshal, under four». «That is not possible. First six, then four, 'cause you moved». He was right, of course (...)” (A. Słonimski, Belweder, [in:] Alfabet wspomnień, p. 18).

25 As in: M.A. Supruniuk, Mieczysław Grydzewski herbu Zerwikaptur, najpokorniejszy stuga literatury, [in:] M. Grydzewski, Silva rerum, selection by J.B. Wójcik, M.A. Supruniuk, Warsaw 2014, p. 54. 
not one accusation even remotely true" 26 . In essence, the author presented a false mirror image of facts. A good example was the allusively Jewish pseudonym 'Neuwert', which Nowaczyński assumed in his youth in order to mark his breaking off with his family. As an offensive 'Gneuwert', it retained a visible reference to the original, but through the grotesque amplification it stressed the awkward association of the pamphleteer with the Jews, so much despised by him: "Gneuwert, a quasi-shabbos goy and really a sad old Jew, now writes only in Polish. Fortunately his grandma, Szyja Gneuwert from Podgórze, can't understand Polish and doesn't know what her grandson, the scoundrel Gneuwert, writes - she would disinherit him from three goats and the metal pot into which several generations of Gneuwerts released their temperament" 27 . That was true; Nowaczyński was born in Podgórze, a satellite village of Kraków at that time. One could add that six months later in Drohobych, the fact of providing the 'Jewish' pseudonym of Nowaczyński by Tuwim and Słonimski, in which readers believed, protected them against being beaten up. In short, as stressed in the punchline of Rudy do budy!, that was how Nowaczyński would have written about himself as a Jew.

What was also accurate was the piece of information that Skamander paid out royalties, albeit modest ones. This is how the fact came from under Słonimski's pen: "This comical figure calls now the Skamander a Jewish aquarium forgetting that he himself was caught for that aquarium following a meagre bait and for fifteen thousand marks revelled and kissed the bigger fishes of the Skamander under the tail. Fortunately, he was flushed together with the dirty water to the sink just in time, and now, disappointed due to his financial hopes, he bespits in helpless anger". Within the reality of that whole range of those mocking insults, there also appeared a pretext for taking voice: "The red Galicia scrooge, ardent yet poorly paid stooge, is frothing at the mouth that Piłsudski watches Szopka Pikadora, because in his party even the very right/left tzaddik Stronski does not laugh at his charades". An apt thought - that puzzling flaw has ever since constituted a tradition of the group. A particularly treacherous trick, then, was to place Nowaczyński's ideological colleagues in a situation of the unacceptable choice between a silenced insinuation and one which was denied - a pseudology known from the trick question: "Do you still beat your wife?" This was how - among others - Makuszyński was 'tricked': "Aron Gneuwert, that hungry and swollen ghoul, with stomach bulging with barley, drunk like a pig prowls bars, toadies to waiters, and disgraces with his company the ashamed Kornel who called him his «precious friend», and being left alone he suggested that his clock was gone".

In this context, the polemicist's humanitarianism becomes clearly ironic: "I can promise one thing: if he ever gets hungry, I will give him, despite everything, one hundred marks. You shouldn't overdo it; all in all,

26 M. Grydzewski, Proroctwa literatów, [in:] Silva rerum, p. 601.

27 Here and further: A. Słonimski, Rudy do budy!, "Skamander" 1923, issue 28, pp. 38-40. The text was included in Dorota Kozicka's forthcoming anthology of the Polish pamphleteers. Cf. "Chamuty”, "gnidy”, „przemilczacze”... antologia dwudziestowiecznego pamfletu literackiego, selection, introduction and editing by D. Kozicka, Kraków 2010, pp. 213-218. 
despite appearances, he is a person". One hundred marks at the exchange rate in the spring of 1923 amounted to slightly over one euro today. After giving alms, Słonimski exacted his coup de grace: "P.S. Dear Adolf! If my column includes some minor elements which might offend you in any way, forgive me as I wrote what you yourself would have written if you were paid well". That punchline modified one of Nagrobki Nowaczyńskiego [Nowaczyński's Headstones], written down before the Great War under the auspices of Andrzej Niemojewski, but originally written by Wincenty Rzymowski:

Księżom i panom dogryzał, Gdzie napluł, potem wylizał.
He stung priests and gentlemen, When he spat, there he licked.

When the fourth act of this story came to be, which I shall discuss in a moment, in Skamander there appeared a note, most certainly by Grydzewski, which was a fair and accurate review of Rudy do budy! The editor wrote:

Słonimski's pamphlet, which was actually immediately understood both by critics and readers, was only an act of turning an assailant's weapon against himself; a vicious mockery and derisive parody of his typical features of style, an intentional construct of truth and falseness, lies and insinuations, charades and paradox. It seemed a pedagogical experiment intended to indicate the possible outcome of a system of irresponsible insults and slander if the sabre of the assailant meets an equally sharp and keen hilt in the hand of a witty and blunt opponent. We do not need to add how much we detest such methods if used s e r i o u s $1 \mathrm{y} .^{28}$

The metaphor of a sword duel seemed a cute anachronism considering that to which the note applied:

Regarding the attempt by a group of academics to force the editorial board of the Skamander to retract the article Rudy do budy! published in the April issue, we published clear and emphatic announcements in the Express Poranny, the Kurjer Polski and the Kurjer Poranny. Today, we once again wish to categorically oppose any attempts which visibly leading to introducing terror into our literary life. The group of the quick-tempered academics has to realise that if they acted in defence of a person from one group, there would certainly emerge people from another group who would be able to oppose such attacks. If, however, they tried to react to inappropriate polemic methods, they should have begun with the one who triggered the above-mentioned article with his pamphlets.

Indeed, there occurred an intrusion into the editorial board of the 'poets' monthly', which could have triggered a revenge which would have been just as brutal. Thus, Skamander mistaken the intention to end the matter amicably

${ }^{28}$ Here and further: "Skamander" 1923, issue 29/30, p. 122. 
for threats. Fortunately, the disturbance unravelled into a farce, which years later offered Grydzewski an opportunity for a vivid reminiscence:

One afternoon in May the editorial board of the Wiadomośc $i^{29}$ was visited (one would assume unwillingly and, possibly, through "being brought") by the very aggrieved party in the company of several students of the university. The board at that time operated from the flat of the editor-in-chief's mother, which, as many flats in that period of bandit invasions, included a hallway with a window with a deadbolt (...) The editor-in-chief (...) having noticed Nowaczyński, knew immediately what was going on and he requested the maid to tell them that he was out, and then he left the flat via another exit. Yet after a moment's thought he realised that sooner or later the enemy will find him (...) In response to the second ring, he heroically opened the door himself. This time Nowaczyński was not there any more, while there still remained his entourage in white-and-amaranth hats, and many more spread through the staircase. (...)

One may assume that if the editorial board was located in a regular office suite, it would have been smashed, yet to smash an office is one thing but to do that to a flat occupied by women and children is another; yet it remains unclear what would have happened if it had not been for the third ring, which was a turning point of the later course of events.

Kazimierz Wierzyński came in, and he rarely came in as a rule, let alone at that time of the day. (...) Having heard the editor-in-chief's account, he said that it was some misunderstanding which he would clarify with Nowaczyński. A telephone call was not possible as the young men cut the line. After overcoming technical difficulties, the telephone conversation ensued, and its friendly character made an impression on the students. There they came to settle accounts with the Jew who published an article by another Jew, one which was insulting for the leading writer of the nationalist camp, and meanwhile they found a Skamandrite who despite not being Jewish was a friend of Jews from the Skamander, and yet he was on a first name basis with Nowaczyński. ${ }^{30}$

Somewhat disappointed, the 'academics' struck back at Grydzewski as they were leaving, saying that he was brave only because he had a revolver in his pocket. Grydzewski did in fact have a small-caliber Browning which he had bought from his barber at a good price, which actually would not have saved him if he had decided to use it. Yet, the trained eye of the radical youth immediately noticed the weapon.

As for Wierzyński, he was proud of his 'deceitful mastery'; Nowaczyński allegedly laughed at the trick; and Grydzewski - while on his way to the editorial board of Kurier Polski with the purpose of composing a protest

${ }^{29}$ The Wiadomości Literackie, founded in 1924 (the first issue was dated 6 January) had apparently already existed in Grydzewski's mind, which was why he thus referred to the Skamander's editorial board (in fact, a private flat). pp. $720-721$.

${ }^{30}$ M. Grydzewski, Dalsze burzliwe dzieje pewnej przyjaźni. Odwrót, [in:] Silva rerum, 
- almost fell victim to a bomb planted on the staircase by unknown culprits. And since the periodical's door faced the door of the editorial board of the rightist Rzeczpospolita, it was impossible to ascertain the intentions of the culprits.

Judging by the further course of events which never unfolded (instead of his lieutenants, Nowaczyński only sent a complaint to the Writers Union, making a complete fool of himself), the antagonists reached an accord. Nowaczyński did not attack Słonimski personally ever again, while Słonimski never reprinted Rudy do budy! in any collection until his death. He might have been cruel, but he was loyal.

\section{REFERENCES}

"Chamuty", "gnidy", "przemilczacze"... antologia dwudziestowiecznego pamfletu polskiego, selection, introduction and editing by D. Kozicka, Kraków 2010.

Grydzewski M., [review of Rudy do budy], "Skamander" 1923, issue 29/30, p. 122.

Grydzewski M., Silva rerum, selection by J.B. Wójcik, M.A. Supruniuk, Warsaw 2014.

Hemar M., Lechoń J., Słonimski A., Tuwim J., Szopki 1922-1931 Pikadora i Cyrulika Warszawskiego, ed. T. Januszewski, Warsaw 2013.

Irzykowski K., Kalamburda warszawski, [in:] K. Irzykowski, Pisma rozproszone, vol. 1, 1897-1922, Kraków 1998. Originally printed in: “Trybuna” 1921, issue 27.

Irzykowski K., Po gościnie u 'Skamandra', “Skamander” 1921, issue 4.

Irzykowski K., Programofobia, "Skamander" 1920, issue 2.

Iwaszkiewicz J., Książka moich wspomnień, Kraków 1983.

Nowaczyński A., L'ex-roi s'amuse, czyli 'Neues Kukiełkes', "Myśl Narodowa” 1923, issue 9, pp. 1-6.

Nowaczyński A., Na występach w Drohobyczu..., "Myśl Narodowa” 1923, issue 49, p. 15.

Nowaczyński A., Nowa szopka Pikusiów, "Myśl Narodowa" 1923, issue 7.

Nowaczyński A., Po zamachu, "Myśl Narodowa" 1922, issue 51, pp. 2-6.

Nowaczyński A., 'Skamander potyska, wiślana świetlacy sięfala', [in:] A. Nowaczyński, Góry z piasku. Szkice, Warsaw 1922. Originally printed in: "Skamander" 1921, issue 7/9.

Nowaczyński A., Testament, “Myśl Narodowa” 1923, issue 1, pp. 4-5.

Nowaczyński A., W pierwszym pułku Pierwszej Brygady, [in:] A. Nowaczyński, Stowa, stowa, stowa..., Warsaw 1938.

Rzymowski W., [Nagrobek Nowaczyńskiemu]. Originally printed in: "Myśl Niepodległa" 1909, issue 115.

Słonimski A., Alfabet wspomnień, Warsaw 1989.

Słonimski A., Kronika Tygodniowa, "Wiadomości Literackie" 1927, issue 25.

Słonimski A., Rudy do budy!, “Skamander" 1923, issue 28, pp. 38-40.

Słonimski A., Załatwione odmownie. Seria druga, Warsaw 1964.

Supruniuk M. A., Mieczysław Grydzewski herbu Zerwikaptur, najpokorniejszy stuga literatury, [in:] Grydzewski M., Silva rerum, selection by J.B. Wójcik, M.A. Supruniuk, Warsaw 2014.

Zaruba J., Z pamiętników bywalca, Warsaw 1968. 


\section{SUMMARY}

The article offers a reconstruction of the text-based fight between Adolf Nowaczyński and Antoni Słonimski. It was not, as it is argued here, only a contest of styles and temperaments - though this exchange proved one of the most impressive, powerful, and dramatic polemics of that time in terms of articulation. However, it stemmed from a long history of tumultuous contacts which offered an amplified view of the problems of identity (Jewishness), politics, and community. A comprehensive view of the combat between Nowaczyński and Słonimski requires both an analysis of the rhetorics of the texts and an investigation into the context and dynamics of publication.

\section{Keywords}

pamphlet, Skamander, szopka comedy play, polemic, nationalism

Eliza Kącka - Ph.D., born in 1982. Assistant professor at the Faculty of Polish Studies, University of Warsaw. She published the following academic books: Stanisław Brzozowski wobec Cypriana Norwida (Warsaw 2012) and Lektura jako spotkanie. Brzozowski - tekst - metoda (Universitas, 2017), as well as fiction: Elizje (Lokator, 2017) and Po drugiej stronie siebie (Lokator, 2019). She was the co-editor of the anthology of recent Polish poetry - Poeci i poetki przekraczaja granice (FA-art, 2011) - and the editor of collections of less recent poetry (including that by Norwid). She is a member of the Executive Board of the Adam Mickiewicz Literary Society. She is a reviewer and avid reader of modern literature.

e-mail: eliza.kacka@gmail.com 